\title{
The ocular surface bacterial contamination and its management in the prophylaxis of post cataract surgery endophthalmitis
}

\author{
Simina Daniela Soare*, Larisa Ilie**, Otilia Costeliu**, Ana Cristina Ghiță***, \\ Liliana Mary Voinea**, Aurelian Mihai Ghiță ${ }^{* * * * * * * * *}$ \\ *Lifecare Eye Clinic, Buftea, Romania \\ **Department of Ophthalmology, University Emergency Hospital, Bucharest, Romania \\ *** Ocularcare Eye Clinic, Bucharest, Romania \\ ****Department of Physiology II, “Carol Davila” University of Medicine and Pharmacy, Bucharest, Romania
}

Correspondence to: Ghiță Aurelian Mihai, MD,

Ocularcare Eye Clinic, Bucharest,

128 Ion Mihalache Boulevard, Code 011240, District 1, Bucharest, Romania,

Mobile phone: +40723 863 438, E-mail: ghita.amg@gmail.com

Accepted: February 15th, 2021

\begin{abstract}
Objective: To investigate the recent pieces of evidence regarding the bacterial ocular surface contamination and its treatment in the prophylaxis of post-cataract surgery endophthalmitis.

Methods: We conducted a literature research on the topic of interest and selected the most relevant data.

Results: The studies reported a relatively high rate of positive conjunctival culture and the most frequently isolated organism was Coagulase negative Staphylococcus, which is also the most common etiological agent of the postoperative endophthalmitis. The bacterial ocular surface load is influenced by age, climate, associated diseases, topical and systemic medication. The use of povidone-iodine alone or in association with levofloxacin eyedrops as prophylactic method is effective in reducing the conjunctival bacterial contamination and consequently decreases the incidence of postoperative endophthalmitis.

Conclusions: Based on the current pieces of evidence, adequate treatment of the bacterial ocular surface contamination prior to cataract surgery seems to be effective in preventing endophthalmitis after cataract surgery.

Keywords: ocular surface, bacterial contamination, prophylaxis of post-cataract surgery endophthalmitis, cataract surgery, bacterial spectrum

Abbreviations: EU = European Union, Spp. = Species, HIV = Human Immunodeficiency Virus
\end{abstract}

\section{Introduction}

Cataract is the leading cause of world blindness, affecting almost 18 million people worldwide [1]. It is responsible for $47.8 \%$ to $51 \%$ of all global blindness [2]. The cataract treatment is relatively easy, safe and cost-efficient and due to the latest advances in the technique and instruments used, it has become the most frequently performed surgical procedure in the world [3]. 4.7 million cataract surgeries were performed in the European Union (EU) in 2017, out of which 77,456 in Romanian hospitals [4]. In 2017, in Romania, 395,44 cataract surgeries were conducted per 100.000 inhabitants, ranking Romania on the 23rd position in the EU [4].
Cataract surgery is one of the safest surgical procedures with a complication rate ranging between $1.7 \%$ and $2.0 \%$. Whilst, most of the periprocedural complications are easy to manage, endophthalmitis, although rare, remains one of the most severe complications leading to high visual morbidity despite appropriate treatment [5-7]. According to different studies, postoperative endophthalmitis incidence varies from 0,04 to $0,2 \%$ [8-11]. The factors known to be associated with endophthalmitis can be divided into two categories: patient-related factors (ocular tear film, ocular adnexa, comorbidities, age, climate, sex and the use of alpha agonists) and factors related to the surgical procedure (irrigation solutions, surgical instruments, respiratory and skin flora of the 
surgeon and nurses, operating theatre air, surgeons' experience) $[\mathbf{6 , 1 2}]$.

The main source of bacteria in postoperative endophthalmitis is the patient's conjunctival flora, which enters in the anterior chamber during the surgical procedure, through incisions. However, the contamination of surgical equipment such as instruments, supplies, prepared solutions, surgical fields, artificial intraocular lenses, should always be taken into consideration $[\mathbf{6 , 1 3 , 1 4}]$.

The etiology of $60 \%$ to $80 \%$ of postoperative endophthalmitis is represented by bacteria found in the eyelid margin and tear film [6]. Among the isolated pathogens, Staphylococcus epidermidis (coagulase-negative) is the most frequently identified (50-85\%), followed by Staphylococcus aureus and Streptococcus Spp. (Species). 20\% of the infections are caused by gram negative microorganisms [15].

Considering the information outlined above, it should be mandatory to analyze the conjunctival swabs and treat any conjunctival contamination prior to cataract surgery.

\section{Methods}

We reviewed the literature and summarized the findings on bacterial conjunctival contamination and its treatment prior to cataract surgery, in order to reduce the incidence of postoperative endophthalmitis.

\section{Results}

Group of risk for high bacterial contamination

Contamination of the conjunctiva is a fact but, the environmental factors, comorbidities and ocular surface changes modified the incidence of bacterial conjunctival contamination and the spectrum. From literature, we highlighted the external and internal conditions associated with an increase of the rate of bacterial contamination.

\section{Climate}

It appears that conjunctival bacterial contamination of patients undergoing cataract surgery presents a seasonal prevalence pattern and this can be considered a risk factor for developing postoperative endophthalmitis during certain months of the year $[\mathbf{1 6 , 1 7}]$. This was stated for the first time by Smith C.H. in 1954 and supported by Rubio, who conducted a study on 4.432 patients, who showed an increased frequency of the positive bacterial results during April, May, and June. Furthermore, Streptococcus pneumoniae had an increased isolation rate in March, November and December, while Haemophilus Spp. had higher isolation rates in January and April $[\mathbf{1 6 , 1 8}]$.
Age

The reviewed studies found that the conjunctival bacterial contamination increases with age, due to a reduction in the local and systemic immunity and to a higher incidence of associated diseases [19]. In a sample of 794 patients, Rubio E.F. found that patients older than 64 years had more conjunctival flora and more conjunctival density than those younger than 65 years [20]. On a larger sample of 19.426 patients, Norregaard et al. showed that advanced age increases the risk of postoperative endophthalmitis due to an increase of the conjunctival bacterial contamination [21]. In a retrospective case-control study on 22.091 enrolled patients, Montan et al. described a trend towards a higher risk of postoperative endophthalmitis in patients older than 81 years [22]. In a study comprising 579 subjects, Chikako et al. showed that patients older than 60 years had a statistically significant higher bacterial contamination rate than the ones younger than 60 years $(\mathrm{p}<0.001)$ [19]. Also, Kawata showed that the positive bacterial culture was related with older age $(p<0,001)$ [23]. The bacterial detection rate according to age was $16.4 \%$ in patients younger than 60 years, $40.7 \%$ in patients aged between 61 and 70 years, 39.9\% in patients aged between 71 and 80 years and $51.5 \%$ in patients older than 81 years [19].

\section{Diabetes mellitus}

The conjunctival flora pattern of diabetic patients is characterized by an increased number of bacteria, which is a predominant cause of many diabetic infections including postoperative endophthalmitis. Several studies on the conjunctival bacterial contamination of diabetic patients were published and showed contradictory results regarding the correlation between diabetes mellitus and positive bacterial cultures. In a study including 590 patients, Kawata et al. showed that patients with diabetes mellitus have a higher rate of positive bacterial culture [23]. De Kaspar found that patients with systemic risk factors, including diabetes mellitus, have a higher risk of positive bacterial culture [24]. These results were supported by further studies showing a higher incidence of positive bacterial culture prior to cataract surgery $[23,25,26]$. However, Chikako et al. showed that there was no statistically significant difference between diabetic and non-diabetic patients [19]. Another study found that diabetic patients are less likely to be colonized by methicillin-resistant organisms $(\mathrm{p}<0.02)$ [27]. Arbab et al. supported this result after studying 80 patients [28].

In a study of 5.922 patients, out of whom 1.325 were diabetics, conducted by Rubio et al., diabetic patients had a higher prevalence of positive conjunctival cultures for Staphylococcus aureus, 
Enterococcus, Streptococcus and Klebsiella spp. [29]. This study also assessed the conjunctival contamination in relation to the creatinine serum levels. $9.27 \%$ of the patients with suspected kidney disease had a higher rate of positive conjunctival bacterial culture $[\mathbf{3 0 , 3 1}]$.

Bilen et al. showed an increased prevalence for Staphylococcus aureus only in patients with type 2 diabetes, but the number of the studied patients was lower than in the study cited above [32]. Martins et al. studied only the patients with diabetic retinopathy and found only an increased prevalence of Staphylococcus coagulase-negative [26]. However, this final study used certain exclusion criteria for their patients, such as external ocular infection or inflammation, which were not used in the study conducted by Rubio. In addition, their patients were younger (mean age was 67 years old), which could have influenced their conjunctival flora [26].

Arbab et al. conducted a study on 80 patients concluding that the presence of diabetic retinopathy increased the risk of positive conjunctival cultures among diabetic patients [28].

Moreover, patients with diabetic retinopathy have a higher likelihood of having $>2$ isolated bacteria from the conjunctival culture than patients without retinopathy [28].

\section{HIV infection}

HIV (Human Immunodeficiency Virus) infection is characterized by a decreased immune response that leads to a higher rate of positive conjunctival cultures. Giles et al. conducted a study on a sample of $104 \mathrm{HIV}$ patients out of whom $62.50 \%$ had positive conjunctival cultures [33]. The study also showed that the conjunctival bacterial load was significantly correlated with the duration of antiretroviral therapy and the degree of immunosuppression. Fontes et al. found similar results (67\%) regarding the rate of positive conjunctival cultures, but showed no correlation between the level of immunosuppression and ocular flora [34]. Gritz et al. found that the conjunctival flora is similar in HIV negative and positive patients [35]. The identified pathogens were similar to those identified by other studies conducted on people without HIV infection: Coagulase-negative Staphylococcus $(90,77 \%)$ and Staphylococcus aureus $(4,61 \%)[33,35]$. However, preventive measures should be taken in HIV patients prior to cataract surgery in order to reduce the risk of developing postoperative endophthalmitis.

\section{Other factors}

Other factors that may influence the conjunctival bacterial contamination are hyperlipidemia, dry eye syndrome and the use of topical ocular medication [36]. Chikako et al. conducted a study that comprised 579 patients who underwent cataract surgery and showed that the factors listed above were associated with significantly lower bacterial detection rates [19]. It is possible that the conjunctival sac and its bacterial flora, which are located upstream of the nasolacrimal duct, might be affected by the changes in the composition of the nasolacrimal duct fluid secondary to hypercholesterolemia. Honda et al. compared bacterial isolation rates from the conjunctival sac between patients receiving topical medication for glaucoma and those not receiving such medication. The bacterial detection rate in the topical medication group was significantly lower than the rate in the group without topical treatment and thus, a washout effect of the eye drops might be involved [37].

Moreover, another prospective study made in Japan found that bacterial isolation rates were significantly lower in patients suffering from dry eye syndrome and actively using eye drops compared to those that did not [37].

Other investigated factors such as HIV, immunosuppression, pregnancy and reproductive status (postmenopausal women versus women of reproductive age) do not interfere with the composition of conjunctival bacterial flora [35].

\section{Incidence of positive cultures}

The reviewed studies found a bacterial conjunctival positivity rate ranging between $12.2 \%$ and $92.85 \%$ [19,38-44] (Table 1). The differences may arise from the fact that the studies were conducted in different regions of the world that are at different levels of development. Only 2 studies were conducted in the same country (India), but the results were contradictory, one study showing a $12.2 \%$ positivity rate whilst the other one a $64 \%$ positivity rate $[\mathbf{4 1 , 4 4}]$. The difference may arise from the fact that Gautam et al. included in the study patients undergoing both cataract and refractive surgery thus, the mean age was younger than the one from Sharma et al., who enrolled only patients undergoing cataract surgery. As previously mentioned, studies showed that an older age leads to a higher rate of positive conjunctival cultures. 
Table 1. Incidence of positive cultures

$\begin{array}{lllll}\text { Author, date } & \text { Country } & \text { Number of eyes included } & \text { Positive } & \text { Negative } \\ \text { Chikako 2012 [19] } & \text { Japan } & 579 & 39.2 \% & 60.8 \% \\ \text { Walker 1986 [38] } & \text { United Kingdom } & 100 & 74 \% & 26 \% \\ \text { Cham 2010 [39] } & \text { Philippines } & 30 & 90 \% & 10 \% \\ \text { Keshav 2012 [40] } & \text { Oman } & 112 & 48.3 \% & 51.7 \% \\ \text { Gautam 2017 [41] } & \text { India } & 500 & 12.2 \% & 87.8 \% \\ \text { Aghi 2016 [42] } & \text { Iraq } & 334 & 92.85 \% & 7.15 \% \\ \text { Reza 2008 [43] } & \text { Pakistan } & 170 & 52.4 \% & 47.6 \% \\ \text { Sharma 2013 [44] } & \text { India } & 200 & 64 \% & 36 \% \\ \text { De Kaspar 2009 [24] } & \text { Germany } & 1474 & 14.9 \% & 85.1 \%\end{array}$

\section{Identified bacteria}

The main source of bacteria causing postoperative endophthalmitis is represented by the indigenous bacteria from the ocular surface [10]. Dong et al. conducted a study that analyses the microbial diversity of the ocular surface by using DNA (Deoxyribonucleic Acid) sequencing-based detection and identification of bacteria. The study found that $96 \%$ of the conjunctival microbiota was represented by the following 12 genera: Pseudomonas, Propionibacterium,

Corynebacterium, Acinetobacter, Brevundimonas, Staphylococci, Aquabacterium, Sphingomonas, Streptococcus, Streptophyta and Methylobacterium [47]. Coagulase-negative Staphylococcus was the most frequently identified bacteria in the conjunctival flora in all the reviewed studies, being isolated in
$18.0 \%$ to $89 \%$ of the conjunctival cultures, making it the most common conjunctival bacteria worldwide. Staphylococcus aureus was identified in 1.8\%-72.31\% of the conjunctival cultures. Corynebacterium spp. was isolated in $1 \%-46.79 \%$ of the conjunctival cultures. Propionibacterium spp. was isolated in $5.4 \%-33.00 \%$ of the conjunctival cultures. Less frequently isolated species were the following: Streptococcus spp. (1.8\%-8\%), Pseudomonas spp. (0,56\%-2\%), Proteus spp. (0.8\%-2\%), Enterococcus spp. (1.8\%-8\%) (Table 2). The disparities found between these studies can be explained by the fact that the studies were conducted in different countries, the number of patients included in the studies ranged between 30 and 5.922 and the mean age of patients varied $[19,24,37-42,44-46]$.

Table 2. Identified bacteria among the studies

\begin{tabular}{|c|c|c|c|c|}
\hline Study & Eyes & $\begin{array}{l}\text { Staphyloccocus } \\
\text { Epidermidis }\end{array}$ & $\begin{array}{l}\text { Staphyloccocus } \\
\text { Aureus }\end{array}$ & $\begin{array}{l}\text { Enterococcus } \\
\text { spp. }\end{array}$ \\
\hline $\begin{array}{l}\text { Rubio et al } 2009 \\
\text { [45] }\end{array}$ & 5922 & $87.32 \%$ & $9.73 \%$ & $2.15 \%$ \\
\hline $\begin{array}{l}\text { De Kaspar } 2009 \\
\text { [24] }\end{array}$ & 1474 & $70,1 \%$ & $3.8 \%$ & \\
\hline Cham et al. [39] & 30 & $89 \%$ & $12 \%$ & $8 \%$ \\
\hline $\begin{array}{l}\text { Faria and Arantes } \\
\text { et al. [46] }\end{array}$ & 50 & $54.0 \%$ & $12.0 \%$ & $2 \%$ \\
\hline Chikako et al. [19] & 579 & $67.0 \%$ & $3.9 \%$ & $2.7 \%$ \\
\hline $\begin{array}{l}\text { Walker et al. } \\
1986 \text { [38] }\end{array}$ & 100 & $58 \%$ & $7 \%$ & - \\
\hline Ohtani 2017 [37] & 68 & $41 \%$ & $8 \%$ & - \\
\hline Kesahv 2012 [40] & 112 & $81,5 \%$ & $1,8 \%$ & $1,8 \%$ \\
\hline $\begin{array}{l}\text { Gautam } 2017 \\
{[41]}\end{array}$ & 500 & $18.0 \% 3$ & $72.31 \%$ & - \\
\hline Aghi 2016 [42] & 334 & $47,10 \%$ & $5.16 \%$ & - \\
\hline Sharma 2013 [44] & 200 & $34 \%$ & $14 \%$ & - \\
\hline
\end{tabular}

\section{Microbial resistance}

Numerous studies evaluated conjunctival bacterial flora and its antibiotic resistance pattern in eyes of the patients undergoing cataract surgery. Tiago Eugenio et al. conducted a retrospective study on 50 patients undergoing cataract surgery, from August to October 2004. Out of 50 eyes, $86 \%$ had positive cultures, the most frequent microorganism being coagulase-negative Staphylococcus, found in $54 \%$ eyes. The isolation of coagulase-negative Staphylococcus showed high susceptibility rate to vancomycin, chloramphenicol, ciprofloxacin, gentamicin, oxacillin, cefotaxime. Staphylococcus aureus was found in $8 \%$ of the eyes and showed a

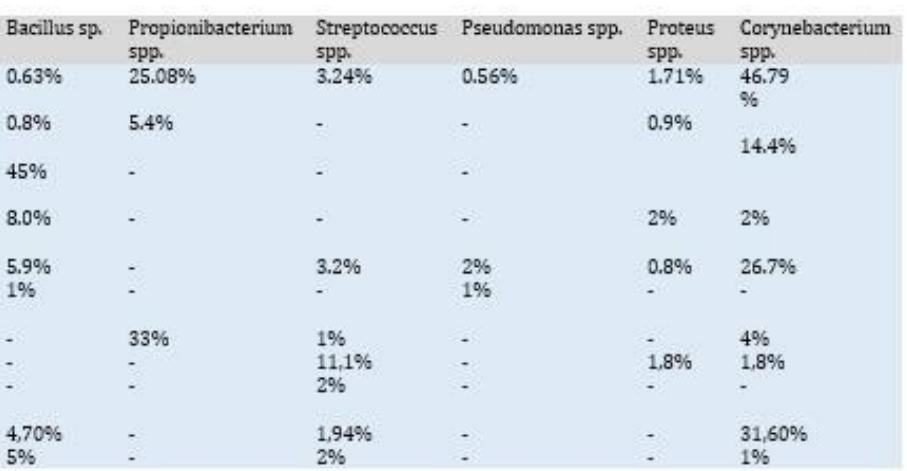

$100 \%$ susceptibility rate to the previously mentioned antibiotics [46].

Rubio et al. conducted a prospective observational study on 1.940 patients undergoing cataract surgery, over a 12 months period. Coagulasenegative Staphylococcus had a prevalence of $88.3 \%$ and showed a high susceptibility rate to vancomycin, gentamicin, ciprofloxacin, and chloramphenicol. Staphylococcus aureus was found in $10.2 \%$ of the eyes and was sensitive to gentamicin, vancomycin, chloramphenicol, ciprofloxacin, and oxacillin. These results were similar to those found in the previous study [45]. 
Kehav R. Belur et al. conducted a prospective study on 56 patients scheduled for cataract surgery. Coagulase-negative Staphylococcus was isolated in $81.5 \%$ of the eyes; maximum sensitivity was achieved with vancomycin, gentamicin, chloramphenicol, and ciprofloxacin (Table 3). Staphylococcus aureus was isolated in $1.8 \%$ of the eyes with a $57 \%$ susceptibility rate to oxacillin and low susceptibility rate to vancomycin, gentamicin, and ciprofloxacin. These results were similar to those found in the studies mentioned above except for the resistance pattern [40] (Table 4).

Table 3. Sensitivity and resistance of Coagulase-negative Staphylococcus to antibiotics according to different literature studies

\begin{tabular}{llllll|ll} 
Tiago & & Gentamicin & Cefotaxime & Oxacillin & Vancomycin & Chloramphenicol & Ciprofloxacin \\
Eugenio & Sensitive & $85.2 \%$ & $85.2 \%$ & $85.2 \%$ & $100 \%$ & $92.6 \%$ & $88.9 \%$ \\
[46] & Resistant & $14.8 \%$ & $7.4 \%$ & $14.8 \%$ & $0 \%$ & $7.4 \%$ & $7.4 \%$ \\
Rubio [45] & Sensitive & $84.7 \%$ & $51.2 \%$ & $51.3 \%$ & $100 \%$ & $96.7 \%$ & $74.3 \%$ \\
& Resistant & $15.3 \%$ & $48.8 \%$ & $48.7 \%$ & $0 \%$ & $3.3 \%$ & $25.7 \%$ \\
Keshav R. & Sensitive & $87 \%$ & - & $50 \%$ & $98 \%$ & $68 \%$ & $84 \%$ \\
Belur [40] & Resistant & $3 \%$ & - & $50 \%$ & $2 \%$ & $32 \%$ & $14 \%$
\end{tabular}

Table 4. Sensitivity and resistance of Staphylococcus aureus to antibiotics in different studies from literature

$\begin{array}{llllllll}\text { Tiago } & & \text { Gentamicin } & \text { Cefotaxime } & \text { Oxacillin } & \text { Vancomycin } & \text { Chloramphenicol } & \text { Ciprofloxacin } \\ \text { Eugenio [46] } & \text { Sensitive } & 100 \% & 100 \% & 100 \% & 100 \% & 100 \% & 100 \% \\ & \text { Resistant } & 0 \% & 0 \% & 0 \% & 0 \% & 0 \% & 0 \% \\ \text { Rubio [45] } & \text { Sensitive } & 94.9 \% & 42.6 \% & 86.2 \% & 100 \% & 98.5 \% & 85.2 \% \\ & \text { Resistant } & 5.1 \% & 57.4 \% & 13.8 \% & 0 \% & 1.5 \% & 14.8 \% \\ \text { Keshav R. R. } & \text { Sensitive } & 74 \% & - & 43 \% & 83 \% & 63 \% & 72 \% \\ \text { Belur [40] } & \text { Resistant } & 26 \% & - & 57 \% & 17 \% & 37 \% & 27 \%\end{array}$

According to the study conducted by Rubio et al., Pseudomonas Aeruginosa was detected less frequently $(0.41 \%)$ and had a high-rate susceptibility for ciprofloxacin, tobramycin, and imipenem. However, in the study conducted by Wolfgang Haas, Pseudomonas had a high rate of resistance for ciprofloxacin, tobramycin, and imipenem. These results may be contradictory due to the different number of patients included in the study: 1.940 patients for Rubio and 56 patients for Belur Kehav [40] (Table 5).

Table 5. Sensitivity and resistance of Pseudomonas Aeruginosa to antibiotics in different studies from literature

$\begin{array}{lllllll}\text { Wolfgang } & & \text { Ciprofloxacin } & \text { Tobramycin } & \text { Imipenem } & \text { Polymyxin B } & \text { Ampicillin } \\ \text { Haas(48) } & \text { Sensitive } & 9.1 \% & 4.5 \% & 11.4 \% & 4.5 \% & - \\ & \text { Resistant } & 90.9 \% & 95.5 \% & 88.6 \% & 95.5 \% & - \\ \text { Rubio(45) } & \text { Sensitive } & 96.4 \% & 96.4 \% & 98.8 \% & - & 30.1 \% \\ & \text { Resistant } & 3.6 \% & 3.6 \% & 1.2 \% & - & 69.9 \%\end{array}$

According to the reviewed studies and medical practice, an increase in the bacterial resistance has been noticed due to the inappropriate and widespread use of antibiotics. The resistance microbial pattern is influenced by the following factors: age, level of care, ethnic group, environment, and antimicrobial prescribing policies used. Therefore, when treating a positive conjunctival culture, the ophthalmologists should take into account the above-mentioned factors and decide when to treat and to use judiciously the antibiotics in order to preserve their efficacy and reduce the microbial resistance [48-50].

\section{Prophylaxis}

Considering the high rate of positive conjunctival culture, preoperative treatment should be applied in order to sterilize the cultures and reduce the risk of postoperative endophthalmitis. The most common used prophylactic methods are povidone iodine and levofloxacin eyedrops.

Povidone-iodine is a potent chemical antiseptic that can be used as a preoperative agent due to its minimal secondary effects and to its proven effect on reducing the conjunctival bacterial load prior to ocular surgery $[\mathbf{5 1 , 5 2}]$. It is mainly used to wipe the eyelids, to flush the upper and lower conjunctival fornixes or it is given in eye drops. Its efficacity was studied since 1984 by Apt and Isenberg on a prospective study of 30 patients undergoing ocular surgery. The number of colonies and species in the povidone-iodine treated eyes decreased by $91 \%$, respectively $50 \%$, compared to the untreated control eyes, and these results were statistically significant [53]. These findings are confirmed by more recent studies showing the effectiveness of povidone-iodine 
in reducing the conjunctival bacterial load preoperatively. In 2012, in a prospective, randomized study on 263 eyes, Nentwich et al. showed that the use of $10 \%$ povidone-iodine drops reduces significantly the number of positive conjunctival cultures [54]. In 2015, Pettey et al. found that 10\% povidone-iodine decreases the bacterial growth by $28 \%$ and the colony counts by $40 \%$ [55]. However, one study showed that low-concentration povidone iodine (5\%) is less effective as the sole antiseptic agent [56]. Ta et al. found no difference between the effectiveness of $10 \%$ and $5 \%$ povidone-iodine in reducing bacterial load [57].

Levofloxacin is a third-generation fluoroquinolone that is used topically because it penetrates the cornea and achieves high intraocular concentrations. Bacteria have high rates of susceptibility to last generation fluoroquinolones compared to ciprofloxacin and ofloxacin [52]. In 2007, ESCRS Study showed a lower incidence of postoperative endophthalmitis in patients treated preoperatively with topical $0.5 \%$ levofloxacin compared to the placebo group (1.5/ 1000 patients versus $2.1 / 1000$ patients) [58].

Another study showed that the bacterial load is decreased by $72.7 \%$ when using topical $0.5 \%$ levofloxacin. The addition of $5 \%$ povidone-iodine increases the bacterial elimination rate to $86.4 \%$. Israel A.R. highlighted that the use of both povidoneiodine and topical levofloxacin is more effective in decreasing the conjunctival bacterial load compared to iodine alone [59].

\section{Conclusions}

Cataract surgery is one of the most frequent surgical procedures performed in the world. Although it is considered as a safe procedure, with manageable complications, postoperative endophthalmitis still remains a sight threatening and challenging complication. Therefore, the most suitable way to avoid this disastrous issue is to prevent it, by adequately treating any preoperatively bacterial contamination known.

A large proportion of conjunctival cultures prove to be positive and correlated with the following factors: age, climate, hyperlipidemia, diabetes mellitus, HIV infection, dry eye syndrome, and the use of topical ocular medication. Older age is associated with a higher risk of postoperative endophthalmitis due to an increased bacterial conjunctival load. The prevalence of the conjunctival bacteria varies according to the period of the year and could predetermine the seasonal incidence of endophthalmitis. Diabetic patients have a higher rate of positive conjunctival cultures, conjunctival bacterial load, sometimes with $>2$ identified bacteria that increases the risk of postoperative endophthalmitis. Additional factors that increase this risk are diabetic retinopathy and diabetic nephropathy, which are indicators of advanced diabetic disease. The conjunctival flora is similar in HIV positive and negative patients, but caution should be taken due to their immunosuppression status that increases the risk of infection. The chronic use of ophthalmic topical medication for diseases such as dry eye syndrome, glaucoma, and other ocular diseases, is associated with significantly lower bacterial rates that can be owed to a washout effect of the eye drops.

The main source of infection is represented by the bacterial flora located on the ocular surface. This is sustained by the fact that the most common pathogen identified globally and the most common causative agent of postoperative endophthalmitis is the Coagulase negative Staphylococcus. It has high susceptibility rate to vancomycin, chloramphenicol, ciprofloxacin, and gentamicin. The second most identified bacteria are Staphylococcus aureus with a high susceptibility rate to gentamicin, oxacillin, vancomycin, chloramphenicol, and ciprofloxacin. Isolated species of Streptococcus, Pseudomonas, Proteus, and Enterococcus were less frequently identified. The widespread use of antibiotics has led to an increase of bacterial resistance making it a serious public health issue that restrains the therapeutic options in front of a patient with positive conjunctival culture. Therefore, practitioners should address this problem by treating any positive conjunctival culture in accordance with the antibiogram result.

It is of vital importance to reduce the risk of postoperative endophthalmitis by applying appropriate methods of prophylaxis. The goal of these prophylactic methods is to sterilize the conjunctival sac prior to intraocular surgery. The most common prophylactic treatment is povidone-iodine alone or in association with levofloxacin eyedrops. Their efficacy in reducing the incidence of postoperative endophthalmitis has been proven by their widespread use over the last 25 years. However, due to the increased antibiotic resistance pattern of conjunctival bacteria, future studies are needed to select the appropriate methods of prophylaxis and find new ones.

\section{Conflict of Interest}

The authors declare no conflict of interest.

\section{Acknowledgements}

None.

\section{Sources of Funding}

None. 


\section{Disclosures}

None.

\section{References}

1. Resnikoff S, Pascolini D, Etya'ale D, Kocur I, Pararajasegaram $\mathrm{R}$, Pokharel GP et al. Global data on visual impairment in the year 2002. Bull World Health Organ. 2004 Nov; 82(11):84451.

2. Study MKRKRBHLSRFJBJJKJLKNKPHPRAWTYWSRHRT for the VLE. Number of People Blind or Visually Impaired by Cataract Worldwide and in World Regions, 1990 to 2010. iovs. 2015; (11):6762-9.

3. Lansingh VC, Carter MJ, Martens M. Global cost-effectiveness of cataract surgery. Ophthalmology. 2007 Sep; 114(9):1670-8.

4. https://appsso.eurostat.ec.europa.eu/nui/submitViewTableA ction.do

5. Low SAW, Braga-Mele R, Yan DB, El-Defrawy S. Intraoperative complication rates in cataract surgery performed by ophthalmology resident trainees compared to staff surgeons in a Canadian academic center. J Cataract Refract Surg. 2018; 44(11):1344-9.

6. Ciulla TA, Starr MB, Masket S. Bacterial endophthalmitis prophylaxis for cataract surgery: an evidence-based update. Ophthalmology. 2002 Jan; 109(1):13-24.

7. Sandvig KU, Dannevig L. Postoperative endophthalmitis: establishment and results of a national registry. J Cataract Refract Surg. 2003 Jul; 29(7):1273-80.

8. Nowak MS, Grzybowski A, Michalska-Małecka K, Szaflik JP, Kozioł M, Niemczyk W et al. Incidence and Characteristics of Endophthalmitis after Cataract Surgery in Poland, during 2010-2015. Int J Environ Res Public Health. 2019 Jun; 16(12).

9. Lloyd JC, Braga-Mele R. Incidence of postoperative endophthalmitis in a high-volume cataract surgicentre in Canada. Can J Ophthalmol. 2009 Jun; 44(3):288-92.

10. Hashemian H, Mirshahi R, Khodaparast M, Jabbarvand M. Post-cataract surgery endophthalmitis: Brief literature review. J Curr Ophthalmol. 2016 Sep; 28(3):101-5.

11. Nam KY, Lee JE, Lee JE, Jeung WJ, Park JM, Park JM et al. Clinical features of infectious endophthalmitis in South Korea: a five-year multicenter study. BMC Infect Dis. 2015 Apr; $15: 177$.

12. Stein JD. Serious adverse events after cataract surgery. Curr Opin Ophthalmol. 2012 May; 23(3):219-25.

13. Kernt M, Kampik A. Endophthalmitis: Pathogenesis, clinical presentation, management, and perspectives. Clin Ophthalmol. 2010 Mar; 4:121-35.

14. Cruciani M, Malena M, Amalfitano G, Monti P, Bonomi L. Molecular epidemiology in a cluster of cases of postoperative Pseudomonas aeruginosa endophthalmitis. Clin Infect Dis an Off Publ Infect Dis Soc Am. 1998 Feb; 26(2):330-3.

15. Speaker MG, Milch FA, Shah MK, Eisner W, Kreiswirth BN. Role of external bacterial flora in the pathogenesis of acute postoperative endophthalmitis. Ophthalmology. 1991 May; 98(5):639-49, discussion 650.

16. Rubio EF. Climatic influence on conjunctival bacteria of patients undergoing cataract surgery. Eye (Lond). 2004 Aug; 18(8):778-84.

17. Smith $\mathrm{CH}$. Bacteriology of the healthy conjunctiva. Br J Ophthalmol. 1954 Dec; 38(12):719-26.

18. Grzybowski A, Brona P, Kim SJ. Microbial flora and resistance in ophthalmology: a review. Graefe's Arch Clin Exp Ophthalmol = Albr von Graefes Arch fur Klin und Exp Ophthalmol. 2017 May; 255(5):851-62.

19. Suto C, Morinaga M, Yagi T, Tsuji C, Toshida H. Conjunctival sac bacterial flora isolated prior to cataract surgery. Infect Drug Resist. 2012; 5:37-41.

20. Rubio EF. Influence of age on conjunctival bacteria of patients undergoing cataract surgery. Eye. 2006; 20(4):447-54.
21. Norregaard JC, Thoning H, Bernth-Petersen P, Andersen TF, Javitt JC, Anderson GF. Risk of endophthalmitis after cataract extraction: results from the International Cataract Surgery Outcomes study. Br J Ophthalmol. 1997 Feb; 81(2):102-6.

22. Silpa-Archa S, Papirachnart A, Singhanetr P, Preble JM. Risk factors for endophthalmitis after cataract surgery in diabetic patients: a case control study. Int J Ophthalmol. 2019; 12(3):417-23.

23. Kawata T, Matsuo T. Positive bacterial culture in conjunctival sac before cataract surgery with night stay is related to diabetes mellitus. BMC Ophthalmol. 2017 Feb; 17(1):14.

24. Miño De Kaspar H, Ta CN, Froehlich SJ, Schaller UC, Engelbert $\mathrm{M}$, Klauss $\mathrm{V}$ et al. Prospective study of risk factors for conjunctival bacterial contamination in patients undergoing intraocular surgery. Eur J Ophthalmol. 2009; 19(5):717-22.

25. Karimsab D, Razak SK. Study of aerobic bacterial conjunctival flora in patients with diabetes mellitus. Nepal J Ophthalmol a Biannu peer-reviewed Acad J Nepal Ophthalmic Soc NEPJOPH. 2013; 5(1):28-32.

26. Martins EN, Alvarenga LS, Höfling-Lima AL, Freitas D, ZoratYu MC, Farah ME et al. Aerobic bacterial conjunctival flora in diabetic patients. Cornea. 2004 Mar; 23(2):136-42.

27. Olson R, Donnenfeld E, Bucci FAJ, Price FWJ, Raizman M, Solomon K et al. Methicillin resistance of Staphylococcus species among health care and nonhealth care workers undergoing cataract surgery. Clin Ophthalmol. 2010 Dec; 4:1505-14.

28. Arbab TM, Qadeer S, Mam SI. Aerobic Bacterial Conjunctival Flora in Diabetic Patients. Pak J Ophthalmol. 2010; 26(4).

29. Fernández-Rubio ME, Rebolledo-Lara L, Martinez-García M, Alarcón-Tomás M, Cortés-Valdés C. The conjunctival bacterial pattern of diabetics undergoing cataract surgery. Eye (Lond). 2010 May; 24(5):825-34.

30. Retnakaran R, Cull CA, Thorne KI, Adler AI, Holman RR. Risk factors for renal dysfunction in type 2 diabetes: U.K. Prospective Diabetes Study 74. Diabetes. 2006 Jun; 55(6):1832-9.

31. Alwakeel JS, Al-Suwaida A, Isnani AC, Al-Harbi A, Alam A. Concomitant macro and microvascular complications in diabetic nephropathy. Saudi J kidney Dis Transplant an Off Publ Saudi Cent Organ Transplantation, Saudi Arab. 2009 May; 20(3):402-9.

32. Bilen H, Ates O, Astam N, Uslu H, Akcay G, Baykal O. Conjunctival flora in patients with type 1 or type 2 diabetes mellitus. Adv Ther. 2007; 24(5):1028-35.

33. Giles K, Bilong Y, Dohvoma AV, Ebana SR, Gonsu H. Conjunctival Flora of Human Immunodeficiency Virus Patients on Antiretroviral Treatment. Ophthalmol Eye Dis. 2017; 9:1179172117724760.

34. Fontes BM, Muccioli C, Príncipe AH, Finamor LP, Höfling-Lima AL, Belfort RJ. Effect of chronic systemic use of trimethoprimsulfamethoxazole in the conjunctival bacterial flora of patients with HIV infection. Am J Ophthalmol. 2004 Oct; 138(4):678-9.

35. Gritz DC, Scott TJ, Sedó SF, Cevallos AV, Margolis TP, Whitcher JP. Ocular flora of patients with AIDS compared with those of HIV-negative patients. Cornea. 1997 Jul; 16(4):400-5.

36. Marini RP, Foltz CJ, Kersten D, Batchelder M, Kaser W, Li X. Microbiologic, radiographic, and anatomic study of the nasolacrimal duct apparatus in the rabbit (Oryctolagus cuniculus). Lab Anim Sci. 1996 Dec; 46(6):656-62.

37. Honda R, Toshida H, Suto C, Fujimaki T, Kimura T, Ohta T et al. Effect of long-term treatment with eyedrops for glaucoma on conjunctival bacterial flora. Infect Drug Resist. 2011; 4:191-6.

38. Walker CB, Claoué CM. Incidence of conjunctival colonization by bacteria capable of causing postoperative endophthalmitis. J R Soc Med. 1986 Sep; 79(9):520-1.

39. Cham TL, Valenton MJ, Ruben Lim Bon Siong M. Ocular bacterial flora and antibiotic sensitivity among Filipino patients undergoing routine cataract surgery. Philipp J Ophthalmol. 34(1). 
40. Keshav BR, Basu S. Normal conjunctival flora and their antibiotic sensitivity in Omanis undergoing cataract surgery. Oman J Ophthalmol. 2012 Jan; 5(1):16-8.

41. Gautam P, Debadatta D, Ankita N, Abhisek Mandal TWB. Comparison of conjunctival microflora in patients undergoing cataract surgery. Indian J Clin Exp Ophthalmol. 34:45-453.

42. Aghi NFS. Normal conjunctival aerobes flora in Erbil city. Polytechnic. 2016; 6(3).

43. Ansari MR, Madani $H$. Conjunctival bacterial flora and antibiotic resistance pattern in patients undergoing cataract surgery. Pakistan J Med Sci. 2008; 244.

44. Sharma PD, Sharma N, Gupta RK, Singh P. Aerobic bacterial flora of the normal conjunctiva at high altitude area of Shimla Hills in India: a hospital based study. Int J Ophthalmol. 2013; 6(5):723-6.

45. Fernández-Rubio E, Urcelay JL, Cuesta-Rodriguez T. The antibiotic resistance pattern of conjunctival bacteria: a key for designing a cataract surgery prophylaxis. Eye (Lond). 2009 Jun; 23(6):1321-8.

46. Arantes TEF, Cavalcanti RF, Diniz M de FA, Severo MS, Lins Neto J, Castro CMMB. Conjunctival bacterial flora and antibiotic resistance pattern in patients undergoing cataract surgery. Arq Bras Oftalmol. 2006; 69(1):33-6.

47. Dong Q, Brulc JM, Iovieno A, Bates B, Garoutte A, Miller D et al. Diversity of bacteria at healthy human conjunctiva. Invest Ophthalmol Vis Sci. 2011 Jul; 52(8):5408-13.

48. Sahm WHJDTMD. Antibiotic Resistance Surveillance of Ocular Pathogens - four years of ARMOR Study Results. ARVO Annu Meet Abstr. 2013; 54(15).

49. Lee AE, Niruttan K, Rawson TM, Moore LSP. Antibacterial resistance in ophthalmic infections: a multi-centre analysis across UK care settings. BMC Infect Dis. 2019; 19(1):768.

50. Tao H, Wang J, Li L, Zhang H-Z, Chen M-P, Li L. Incidence and Antimicrobial Sensitivity Profiles of Normal Conjunctiva Bacterial Flora in the Central Area of China: A Hospital-Based Study. Frontiers in Physiology. Vol. 8, 2017, 363.

51. Binder C, de Kaspar HM, Engelbert M, Klauss V, Kampik A. Bacterial colonization of conjunctiva with Propionibacterium acnes before and after polyvidon iodine administration before intraocular interventions. Ophthalmologe. 1998 Jun; 95(6):438-41.

52. Kampik A. Comparison of Conjunctival Application of Topical $0.5 \%$ Levofloxacin and 1\% Povidone-Iodine Flushing versus Povidone-Iodine alone in Patients undergoing Intraocular Surgery: A Prospective Randomized Study. Available from: https://www.researchgate.net/publication/242262377_Com parison_of_Conjunctival_Application_of_Topical_05_Levofloxa cin_and_1_PovidoneIodine_Flushing_versus_Povidone_Iodine_alone_in_Patients_undergoing_Intraocular_Surgery_A Prospective_Randomized_Study

53. Apt L, Isenberg S, Yoshimori R, Paez JH. Chemical preparation of the eye in ophthalmic surgery. III. Effect of povidone-iodine on the conjunctiva. Arch Ophthalmol (Chicago, 1960). 1984 May; 102(5):728-9.

54. Nentwich MM, Rajab M, Ta CN, He L, Grueterich M, Haritoglou $C$ et al. Application of $10 \%$ povidone iodine reduces conjunctival bacterial contamination rate in patients undergoing cataract surgery. Eur J Ophthalmol. 2012; 22(4):541-6.

55. Pettey JH, Mifflin MD, Olson RJ. Study of the Acute Effects of Povidone-Iodine on Conjunctival Bacterial Flora. J Ocul Pharmacol Ther Off J Assoc Ocul Pharmacol Ther. 2015 Dec; 31(10):627-30.

56. Lam PTH, Hui M, Young AL, Chan CY, Lam DSC. Preoperative Antisepsis With Povidone-Iodine $5 \%$ in Cataract Surgery. Asia-Pacific J Ophthalmol (Philadelphia, Pa). 2012; 1(2):7783.

57. Ta CN, Singh K, Egbert PR, de Kaspar HM. Prospective comparative evaluation of povidone-iodine $(10 \%$ for 5 minutes versus $5 \%$ for 1 minute) as prophylaxis for ophthalmic surgery. J Cataract Refract Surg. 2008; 34(1).
58. Kessel L, Flesner P, Andresen J, Erngaard D, Tendal B, Hjortdal J. Antibiotic prevention of postcataract endophthalmitis: a systematic review and meta-analysis. Acta Ophthalmol. 2015 Jun; 93(4):303-17.

59. Miño de Kaspar H, Kreutzer TC, Aguirre-Romo I, Ta CN, Dudichum J, Bayrhof $\mathrm{M}$ et al. A prospective randomized study to determine the efficacy of preoperative topical levofloxacin in reducing conjunctival bacterial flora. Am J Ophthalmol. 2008 Jan; $145(1): 136-42$. 